\title{
A PRODUCTION PLANNING OF MIXED CHAMPIGNON PRODUCT TO OPTIMIZE PROFIT GAINED BY PT X
}

\section{PERENCANAAN PRODUKSI KOMBINASI PRODUK JAMUR KANCING UNTUK MENGOPTIMALKAN KEUNTUNGAN DI PT X}

\author{
Muhammad Arif Darmawan*) and Karsi Widiawati \\ Department of Agroindustrial Technology, Faculty of Agricultural Technology, IPB University, \\ Jl. Raya Dramaga, Bogor, Jawa Barat, Indonesia \\ *Email: arifdarma1@ apps.ipb.ac.id
}

Makalah: Diterima 09 September 2020; Diperbaiki 19 November 2020; Disetujui 10 Desember 2020

\begin{abstract}
ABSTRAK
PT X adalah perusahaan di bidang agroindustri khususnya pada komoditas jamur kancing. Jamur kancing memiliki umur simpan yang pendek sehingga harus segera dijual ke konsumen atau diproses menjadi produk olahan. Jumlah permintaan jamur tidak pasti, menyebabkan terjadinya kelebihan atau kekurangan produksi baik pada produk segar maupun olahan. Oleh karena itu, perlu untuk menghitung rencana kombinasi produk yang dapat memenuhi tujuan yang diinginkan dan mendapatkan solusi yang memuaskan. Penelitian ini menggunakan metode goal programming dalam perencanaan produk kombinasi. Penelitian ini juga menggunakan permintaan produk dan ketersediaan bahan baku dari Januari 2017 hingga Desember 2019. Selain itu, data kebutuhan bahan baku, jam tenaga kerja, biaya produksi, dan harga setiap produk juga digunakan. Data historis terkait jumlah permintaan dan ketersediaan bahan baku digunakan untuk meramalkan jumlah permintaan dan ketersediaan bahan baku pada periode perencanaan menggunakan model ARIMA. Penentuan tingkat prioritas yang digunakan dalam pemodelan goal programming pada penelitian ini menggunakan pairwise comparison. Berdasarkan hasil perencanaan yang telah dibuat untuk bulan Januari 2020, total jumlah produksi fresh champignon yaitu $22.584 \mathrm{~kg}$, produk $250 \mathrm{~mL}$ whole champignon sebanyak 4.499 unit, produk $900 \mathrm{~mL}$ whole champignon sebanyak 2.571 unit, produk $250 \mathrm{~mL}$ sliced champignon sebanyak 4.567 unit, produk $900 \mathrm{~mL}$ sliced champignon sebanyak 32.306 unit, dan produk canned champignon sebanyak 85 unit. Model peramalan yang digunakan dalam penelitian ini representatif berdasarkan verifikasi yang telah dilakukan.
\end{abstract}

Kata kunci: jamur kancing, goal programming, perencanaan produksi, ARIMA

\section{ABSTRACT}

PT $\mathrm{X}$ is an agroindustry which focuses on the champignon commodities. Champignon has a short shelf life, so it must be sold directly to consumers or processed into champignon preserved products. The number of the champignon demand is uncertain causes excess or lack of stock on both fresh champignon and champignon preserved products. Therefore, it is necessary to calculate the product combination plan that can meet the desired objectives and obtain a satisfying solution. This study uses the goal programming method to make product combination planning. This study also used data of the products demand and raw materials from January 2017 to December 2019. In addition, data of man hours, production costs, and prices of each type of product were also used. Historical data of demand and raw materials were used to predict the level of products demand and raw materials in the planning period using ARIMA models. Determination of priority levels in the goal programming modeling of this study was done using pairwise comparison. Based on the planning results that has made for January 2020, the total production of fresh mushroom was $22,584 \mathrm{~kg}, 250 \mathrm{ml}$ whole champignon was 4,499 pieces, $900 \mathrm{~mL}$ whole champignon was 2,571 pieces, $250 \mathrm{~mL}$ sliced champignon was 4,567 pieces, $900 \mathrm{~mL}$ of sliced champignon wass 32,306 pieces, and canned champignon was 85 pieces. The verification of the model showed that the forecast model used in this study was representative.

Keywords: champignon, production planning, goal programming, ARIMA, pairwise comparison

\section{INTRODUCTION}

Mushroom has good prospect in the food industry. One type of mushroom that has good prospects is Agaricus bisporus which is also called as champignon, is a healthy food that is widely consumed in the global food market for $15 \%$ of total worldwide mushroom production (Ramos et al., 2019). This mushroom has a round shape like a button with white or yellowish-white color. Besides of having a delicious taste, mushrooms also have a high nutritional composition that can help to fulfill human's daily nutritional needs. The most important benefits of champignon are its dietary and healing properties resulting from the rich biologically active elements including dietary fiber, amino acids, digestible protein, antioxidants, vitamins, and bioelements (Muszyńska et al., 2017). Champignon has 
high perishability characteristics because it has high initial microbial content (Akram et al., 2012). The champignon is easy to have quality deterioration and nutritional loss because there is no protective epicuticle layer on the surface. This causes the champignon must be sold immediately to consumers or processed into champignon preserved products.

PT $\mathrm{X}$ is a company which focuses on agroindustry especially in mushroom commodities. Consumer demands of mushrooms is uncertain. On the other hand, mushroom products are sold with two options, namely fresh champignon and champignon preserved product. This uncertainty sometimes makes excess or lack of stock on both fresh champignon and champignon preserved products. This is a problem because the company does not use good production planning. The production planning used by the company is to meet the demand for fresh champignon products first then the remaining raw materials will be used to produce the preserved champignon products. Therefore the calculation of the product combination of champignon production of PT X needs to be done to get the optimal solution which includes the number of products demands and the availability of raw materials forecast, and the distribution of raw materials for each type of product based on the priority level of each company objective.

Production planning is determining the level of product produced in accordance with the forecast demand, it is one of the important factors of manufacturing companies. Production planning is complicated because it requires cooperation among multiple functional units (Komsiyah et al., 2018). The plan provides the best solution so that the produced products optimally satisfy with both consumers in terms of demand fulfillment and producers in terms of the availability of resources and revenue target. Without good production planning, companies can not implement efficient production processes which lead to high cost that is needed for the production process. In addition, it can also reduce the quality of products produced (Vincent et al., 2018). The objective of this study was to determine an optimal amount of each type of product based on the limited availability of resources, the number of demand, and the expected income. Companies can use the goal programming methods to determine which alternative is suitable for the company. Goal programming can minimize the deviation of the objective constraint and the production levels to achieve the desired goal (Ho, 2019).

The products produced by PT X are fresh champignons and champignon preserved products. Products demand that varies every day makes it difficult for the company to determine the right amount and combination of products to be produced. Demand forecast of products and raw materials are needed. Based on these forecasts, model is made to obtain production plan that can provide a satisfying solution. This production plan is used by the company to achieve its goals. Based on this problem, the research was made to establish champignon product combination plans to maximize profit obtained by PT $\mathrm{X}$.

\section{RESEARCH AND METHOD}

\section{Thinking Framework}

The champignon product combination planning at PT X begun with collecting the data related to the product combination planning. The data needed for period of January 2017 to December 2019. It was related to the number of sales, demands, and raw materials. Moreover, data on raw material, man hours, production costs, and prices of each type of product are also needed. Historical demand data was used to predict the level of demand for the planning period. This demand prediction data was combined with data of raw materials availability, man hour availability, production cost requirements, and product selling prices to plan the champignon product combination. After all the required data have been collected, then the constraints that affect the production process was modelled. Then, the objective function formulation was carried out. To do so, variable weighting was needed based on the priority level.

The weightage can be made by using pairwise comparison. After that, the planned model is combined by using the goal programming model. Amalia et al. (2016) concluded that the optimization of production costs of mineral water products using the goal programming method, the results show that the profits obtained by the company were greater when using this method. Tiwari et al. (2018) stated that the goal programming method makes it possible to include all objectives in the desired priority.

\section{Procedure of Data Analysis \\ Observation of Production Activities at PT X}

The products produced by PT $\mathrm{X}$ consist of products with and without processing. All of these products come from the same raw material so that the champignon production activities at PT $\mathrm{X}$ are strongly influenced by the availability of raw materials, the number of demands, production costs, the product prices, and working hours.

\section{Problem Identification}

From the observation of production activities at PT X, several problems were found. Those problems included how to produce many types of products based on existing demands, how to utilize all available raw material and man hours, how to minimize the costs needed, and how to meet the production targets set by the company.

\section{Problem Limitation}

The limitation purpose is simply to facilitate the assessment process that is adapted to the 
conditions of the company and the ability of the planned model. The determination of limitations in this study was carried out by conducting literature studies on production planning and surveys to PT X. Limitation problems and assumptions used in this research study were:

1. The planning period made was short-term planning, which is applicable for a month.

2. There was no quality differentiation in raw materials or fresh champignon products.

3. The price of fresh champignon products used was the average price of each type of fresh champignon product.

4. The price of raw materials was assumed to be unchanged for the planning period.

Forecast of Raw Material Availability and Products Demand

In this product combination plan, the forecast for raw material availability and products demand is needed. The forecasting method is carried out using historical data or commonly called time series. Time series is an observation of random variables found in overtime (Hillier and Lieberman, 2001). The time series method used in this study is the Box-Jenkins method or commonly called ARIMA. The ARIMA method is a combination of the moving average and regression methods. It is able to forecast data that has a stationary, trend and seasonal pattern. The forecasting in this study is done by using Minitab application.

\section{Model Development}

Production planning is a complex planning because it includes various criteria. Goal programming is a model that enables companies to achieve an optimal balance between competing factors that they face in pursuing the overall goals of the company. Goal programming has been widely applied and proven effective in decision making problems (Kouaissah and Hocine, 2020). In determining production planning, companies need to pay attention to various factors that affect their overall goals. To reach a satisfying solution, it must be in accordance with the conditions, such as the availability of resources, objective constraints, and others (Anis et al., 2017). The key element of the goal programming model is the objective function that contains undesirable variable deviations (Hocine et al., 2020).

\section{Decision Variable Identification}

The decision variable describes the amount of product that the decision maker wants to determine (Jones et al., 2010). The selected decision variable in PT X was derived from PT X's production activities. The decision variables in this goal programming model were presented in Table 1 .

\section{Objective Constraints}

The production process of PT $\mathrm{X}$ was influenced by raw materials, production costs, and the number of workers. The formulation of goal programming constraints can be seen in Table 2 .

\section{Priority Level Selection}

The determination of priority levels was carried out to rank objectives and deviation variables based on their priorities. Each priority level was distinguished by using different weights. The grouping of objective constraint on their priorities was determined using the pairwise comparison. The pairwise comparison allows the importance of a criterion relative to other criteria to be clearly stated. Through pairwise comparison, priority level are obtained by analyzing the comparison matrices (Liu et al., 2020).

Table 1 . The decision variables in the goal programming model

\begin{tabular}{llc}
\hline \multicolumn{1}{c}{ Activity } & \multicolumn{1}{c}{ Decision Variable } & Symbol \\
\hline Fresh champignon production & Fresh champignon & $\mathrm{x}_{1}$ \\
$250 \mathrm{ml}$ whole champignon production & $250 \mathrm{~mL}$ sliced champignon & $\mathrm{x}_{2}$ \\
$900 \mathrm{ml}$ whole champignon production & $250 \mathrm{~mL}$ whole champignon & $\mathrm{x}_{3}$ \\
$900 \mathrm{ml}$ sliced champignon production & $900 \mathrm{~mL}$ sliced champignon & $\mathrm{x}_{4}$ \\
$900 \mathrm{ml}$ sliced champignon production & $900 \mathrm{~mL}$ whole champignon & $\mathrm{x}_{5}$ \\
Canned champignon production & Canned champignon & $\mathrm{x}_{6}$ \\
\hline
\end{tabular}

Table 2. The formulation of goal programming constraints

\begin{tabular}{ccc}
\hline Initial form & Changed form & $\begin{array}{c}\text { Variable deviation to be } \\
\text { changed }\end{array}$ \\
\hline$f_{i}(x) \geq b_{i}$ & $f i(x)+d_{i}^{-}-d_{i}^{+}=b_{i}$ & $d_{i}^{-}$ \\
$f_{i}(x) \leq b_{i}$ & $f i(x)+d_{i}^{-}-d_{i}^{+}=b_{i}$ & $d_{i}^{+}$ \\
$f_{i}(x)=b_{i}$ & $f_{i}(x)+d_{i}^{-}-d_{i}^{+}=b_{i}$ & $d_{i}^{-}+d_{i}^{+}$ \\
\hline
\end{tabular}




\section{RESULT AND DISCUSSION}

\section{PT X Overview}

\section{PT X Profile}

PT $\mathrm{X}$ focuses on processing agricultural products with the main commodity of champignon (Agaricus bisporus). It produces processed champignon, various Indonesian dishes, and meat products. In the beginning, PT X was divided into four locations. The first location is the mushroom processing place, the second location is the mushroom composting place, the third location is the mushroom seedling place, and the fourth location is the mushroom planting place.

\section{PT X Production Process.}

The champignon processed product in PT $\mathrm{X}$ is processed through 19 processing stages, namely receiving, washing, blanching, cooling, first shaking, grading, sorting, slicing, second shaking, dewatering, filling, brining, exhausting, seaming, crating, sterilization, cleaning, labeling, and storage.

\section{Forecast of Raw Material Availability and Products Demand}

Forecasting the number of products demands and the availability of the raw materials is needed in goal programming method to plan the product combination. The forecasting method used is ARIMA. Autoregressive integrated moving average models, or ARIMA models, incorporate this dependent structure of data to generate the forecast (Montgomery et al., 2008). ARIMA method is able to collect all data patterns for forecasting.

In this study, the data used were historical data at PT X related to the number of products demands and the availability of the raw materials from January 2017 to December 2019. The stages of the ARIMA method according to Montgomery et al. (2008) include model identification, parameter estimation, model diagnostics, and forecasts. Forecasting the number of products demands and the availability of the raw materials followed those method stages.

\section{Model Identification}

The main requirement in this ARIMA method is that the data must be stationary on both on its average and its variety. The estimation results of the $\lambda$ values can be seen in Table 3 .

The next step is determining the stationary type of the data to the average. If the data is not stationary with time, it can be modified by differentiating the data. Based on the result of the autocorrelation correlogram that has been carried out, there was one data that requires differentiation, it was the data on fresh champignon demand.

Parameter Estimation
Parameter estimation was done by looking at the estimated P-Value of each model parameter from all iterations that have been made. The estimated PValue that is under 0.05 indicates that this parameter is significant. If all P-Value values are significant, then continue to the diagnostic stage.

Table 3. Estimated $\lambda$ result

\begin{tabular}{lc}
\hline \multicolumn{1}{c}{ Type of Data } & Estimation of $\boldsymbol{\lambda}$ \\
\hline Raw material availability & 1.00 \\
Fresh champignon demand & 0.00 \\
$250 \mathrm{~mL}$ whole champignon & 1.00 \\
demand & \\
$900 \mathrm{~mL}$ whole champignon & -0.05 \\
demand & \\
$250 \mathrm{~mL}$ sliced champignon & 0.50 \\
demand & \\
$900 \mathrm{~mL}$ sliced champignon & 1.00 \\
demand & \\
Canned champignon demand & 0.09 \\
\hline
\end{tabular}

\section{Model Diagnostics}

Model estimation was done by looking at the Ljung-Box P-Value of each model parameter. The model's Ljung-Box P-Value must have a value of more than 0.05 which indicate that the remaining time series are independent. The model that has the remaining time series which are independent of each other shows that the model is suitable to be used to predict the availability of raw material and products demand. The chosen model has the smallest MSE value. The selected ARIMA model can be seen in Table 4 .

Table 4. Selected ARIMA model

\begin{tabular}{lc}
\hline \multicolumn{1}{c}{ Type of Data } & ARIMA Model \\
\hline Raw material availability & $1,0,1$ \\
Fresh champignon demand & $3,1,2$ \\
$250 \mathrm{~mL}$ whole champignon & $1,0,1$ \\
demand & \\
$900 \mathrm{~mL}$ whole champignon & $5,0,4$ \\
demand & \\
$250 \mathrm{~mL}$ sliced champignon & $1,0,1$ \\
demand & \\
$900 \mathrm{~mL}$ sliced champignon & $1,0,2+\mu$ \\
demand & \\
Canned champignon demand & $2,0,2+\mu$ \\
\hline
\end{tabular}

\section{Forecasts}

The forecast is used to predict the availability of raw material and products demand. Forecasting was done by using the selected forecasting model based on the model diagnosis that has been done. The forecast result of the availability of raw material and products demand can be seen in Table 5. 
Table 5. Forecasting result

\begin{tabular}{lc}
\hline Type of Data & Forecast for January 2020 \\
\hline Raw material availability (kg) & 39,986 \\
Fresh champignon demand (kg) & 30,280 \\
250 mL whole champignon demand (items) & 4,499 \\
900 mL whole champignon demand (items) & 2,571 \\
250 mL sliced champignon demand (items) & 4,567 \\
900 mL sliced champignon demand (items) & 7,689 \\
Canned champignon demand (items) & 85 \\
\hline
\end{tabular}

\section{Goal Programming Models}

Goal programming is a method of decision making that is based on mathematical foundations, so it represents mathematical reality in more accurately. ARIMA is a time series model which value changes over time, in this study the time series period used was per month. The goal programming model is used for fixed data. Because of that, this model was valid for a month because for the next period the form of the equations will change. Bakhtavar et al. (2020) explained that the concept of goal programming begins with conducting pairwise comparisons to weight different goals with conflicting priorities to find the best solution. The objective constraints of this plan are obtained from the results of discussions with the company's management team and from the literature review results related to factors that can affect the sustainability of the production process in the company. The goal programming method can be made by determining the objective constraint equation. Then, the priority level of each objective constraint is weighted. The last step that must be done is determining the objective function based on the objective constraints and the priority level.

\section{Objective Constraints}

Production Maximizes The Use of Available Raw Materials

The raw material needed in the production process at PT $\mathrm{X}$ is champignon which comes from the company branch engaged in the champignon plantation. This cause the amount of raw material is uncertain as it depends on the yield of the branch. PT $\mathrm{X}$ must accept any harvest obtained by the branch plantation. Based on the forecasted available raw material obtained was $39,986 \mathrm{~kg}$. Each product requires different amount of raw materials, it can be seen in Table 6.

Based on the raw materials needed for each product and the forecast of the raw material availability, the equation model can be made as follows:

$1,000 \mathrm{x}_{1}+130 \mathrm{x}_{2}+470 \mathrm{x}_{3}+128 \mathrm{x}_{4}+460 \mathrm{x}_{5}+1,928 \mathrm{x}_{6}=$ $39,986,100$

so that

$1,000 x_{1}+130 x_{2}+470 x_{3}+128 x_{4}+460 x_{5}+1,928 x_{6}+$ $\mathrm{d}_{2}-\mathrm{d}_{1}=39,986,100$

Where $\mathrm{d}_{1} \quad$ : Positive deviation of the use of available raw material in January 2020

$\mathrm{d}_{2} \quad$ : Negative deviation of the use of available raw material in January 2020

Based on the equation above, to maximize the use of available raw material, it needs to

$\operatorname{Min} Z=d_{1}+d_{2}$

Table 6. Number of raw material needed

\begin{tabular}{lc}
\hline \multicolumn{1}{c}{ Product } & $\begin{array}{c}\text { Champignon Needed } \\
(\mathbf{g})\end{array}$ \\
\hline Fresh champignon & 1,000 \\
$250 \mathrm{~mL}$ whole champignon & 130 \\
$900 \mathrm{~mL}$ whole champignon & 470 \\
$250 \mathrm{~mL}$ sliced champignon & 128 \\
$900 \mathrm{~mL}$ sliced champignon & 460 \\
Canned Champignon & 1,928 \\
\hline
\end{tabular}

\section{Production meets demand}

The second objective constraint was fulfilling the demand of products. Fulfilling this demand was done to maximize sales. In addition, the fulfillment of products demand was also carried out to improve the good relationship between PT X and customers. The forecast of products demand for each product can be seen in Table 5. Based on the products demand data, the equation model can be made as follows.

$$
\begin{aligned}
& \mathrm{x}_{1}=30,280 \\
& \mathrm{x}_{2}=4,499 \\
& \mathrm{x}_{3}=2,571 \\
& \mathrm{x}_{4}=4,567 \\
& \mathrm{x}_{5}=7,689 \\
& \mathrm{x}_{6}=85
\end{aligned}
$$

so that

$$
\begin{aligned}
& \mathrm{x}_{1}+\mathrm{d}_{4}-\mathrm{d}_{3}=30,280 \\
& \mathrm{x}_{2}+\mathrm{d}_{6}-\mathrm{d}_{5}=4,499 \\
& \mathrm{x}_{3}+\mathrm{d}_{8}-\mathrm{d}_{7}=2,571 \\
& \mathrm{x}_{4}+\mathrm{d}_{10}-\mathrm{d}_{9}=4,567 \\
& \mathrm{x}_{5}+\mathrm{d}_{12}-\mathrm{d}_{11}=7,689 \\
& \mathrm{x}_{6}+\mathrm{d}_{14}-\mathrm{d}_{13}=85
\end{aligned}
$$

Where

$d_{3}$ : Positive deviation from meeting demand of fresh champignon in January 2020

$\mathrm{d}_{4} \quad$ : Negative deviation from meeting demand of fresh champignon in January 2020 
$\mathrm{d}_{5} \quad$ : Positive deviation from meeting demand of $250 \mathrm{~mL}$ whole champignon in January 2020

$\mathrm{d}_{6} \quad$ : Negative deviation from meeting demand of $250 \mathrm{~mL}$ whole champignon in January 2020

$\mathrm{d}_{7} \quad$ : Positive deviation from meeting demand of $900 \mathrm{~mL}$ whole champignon in January 2020

$\mathrm{d}_{8} \quad$ : Negative deviation from meeting demand of $900 \mathrm{~mL}$ whole champignon in January 2020

$\mathrm{d}_{9}$ : Positive deviation from meeting demand of $250 \mathrm{ml}$ sliced champignon in January 2020

$\mathrm{d}_{10}:$ Negative deviation from meeting demand of $250 \mathrm{~mL}$ sliced champignon in January 2020

$\mathrm{d}_{11}$ : Positive deviation from meeting demand of $900 \mathrm{~mL}$ sliced champignon in January 2020

$\mathrm{d}_{12}$ : Negative deviation from meeting demand of $900 \mathrm{~mL}$ sliced champignon in January 2020

$\mathrm{d}_{13}$ : Positive deviation from meeting demand of canned champignon in January 2020

$\mathrm{d}_{14}$ : Negative deviation from meeting demand of canned champignon in January 2020

Based on the equation above, to fulfill the products demand, it needs to

Min $Z=d_{3}+d_{4}+d_{5}+d_{6}+d_{7}+d_{8}+d_{9}+d_{10}+d_{11}+$ $\mathrm{d}_{12}+\mathrm{d}_{13}+\mathrm{d}_{14}$

\section{Production Maximizes Revenue}

The third objective constraint is maximizing revenue. Sales revenue obtained from the product sales. Each product has a different price. The price of products produced by PT X can be seen in Table 7 .

Table 7. Price of products

\begin{tabular}{lc}
\hline \multicolumn{1}{c}{ Product } & Price \\
\hline Fresh champignon & 18,000 \\
250 ml whole champignon & 9,000 \\
900 ml whole champignon & 26,000 \\
250 ml sliced champignon & 9,000 \\
900 ml sliced champignon & 26,000 \\
Canned Champignon & 60,000 \\
\hline
\end{tabular}

The revenue target in PT X is 1400000000 per month. Based on the data of each product price and sales revenue target, the equation model can be made as follows.

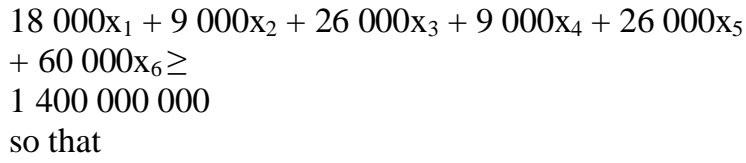

$18000 \mathrm{x}_{1}+9000 \mathrm{x}_{2}+26000 \mathrm{x}_{3}+9000 \mathrm{x}_{4}+26$

$000 \mathrm{x}_{5}+60000 \mathrm{x}_{6}+\mathrm{d}_{15} \geq$

1400000000

Where

$\mathrm{d}_{15}$ : Negative deviation of total revenue in January 2020

Based on the equation above, to maximize the revenue, it needs to

Min $Z=d_{15}$

Production minimizes production costs

The fourth objective constraint was minimizing the production costs. Each type of product produced by $\mathrm{PT} \mathrm{X}$ requires different production costs. These production costs include the cost of raw materials, additives, and labor. Production costs at PT X are less than 1,000,000,000 per month. The production cost for each product produced by PT $\mathrm{X}$ can be seen in Table 8 .

Table 8 Production cost of each product

\begin{tabular}{cc}
\hline \multicolumn{1}{c}{ Product } & Cost (Rp) \\
\hline Fresh champignon & 14,400 \\
$250 \mathrm{~mL}$ whole champignon & 5,850 \\
$900 \mathrm{~mL}$ whole champignon & 16,900 \\
$250 \mathrm{~mL}$ sliced champignon & 5,850 \\
$900 \mathrm{~mL}$ sliced champignon & 16,900 \\
Canned Champignon & 39,000 \\
\hline
\end{tabular}

Based on the needed production costs of each product and the total production cost available, the equation model can be made as follows:

$14,400 \mathrm{x}_{1}+5,850 \mathrm{x}_{2}+16,900 \mathrm{x}_{3}+5,850 \mathrm{x}_{4}+16,900 \mathrm{x}_{5}$ $+39,000 x_{6} \leq 1,000,000,000$

so that

$14,400 \mathrm{x}_{1}+5,850 \mathrm{x}_{2}+16,900 \mathrm{x}_{3}+5,850 \mathrm{x}_{4}+16,900 \mathrm{x}_{5}$ $+39000 \mathrm{x}_{6}-\mathrm{d}_{16} \leq 1,000,000,000$

Based on the equation above, to minimize the production cost, it needs to

$\operatorname{Min} \mathrm{Z}=\mathrm{d}_{16}$

\section{Production Maximizes The Use of Man Hours}

The fifth objective constraint was maximizing the use of available man hour. This was done to minimize the excess or lack of man hours. The total availability of man hours in PT X was 6,476 man hour per month. The amount of man hour required by each product produced by PT X can be seen in Table 9 .

Based on the man hour requirements of each product and the total man hour available in PT X, the equation model can be made as follows:

$0.027500 \mathrm{x}_{1}+0.049539 \mathrm{x}_{2}+0.179104 \mathrm{x}_{3}+$ $0.048777 \mathrm{x}_{4}+0.175294 \mathrm{x}_{5}+0.409802 \mathrm{x}_{6}=6476$

so that

$0.027500 \mathrm{x}_{1}+0.049539 \mathrm{x}_{2}+0.179104 \mathrm{x}_{3}+$ $0.048777 \mathrm{x}_{4}+0.175294 \mathrm{x}_{5}+0.409802 \mathrm{x}_{6}+$ 
$d_{18}-d_{17}=6476$

Based on the equation above, to maximize the use of available man hour, it needs to

$$
\operatorname{Min} \mathrm{Z}=\mathrm{d}_{17}+\mathrm{d}_{18}
$$

Table 9. Needs for man hours

\begin{tabular}{lc}
\hline \multicolumn{1}{c}{ Product } & Man Hour/Item \\
\hline Fresh champignon & 0.027500 \\
$250 \mathrm{ml}$ whole champignon & 0.049539 \\
$900 \mathrm{ml}$ whole champignon & 0.179104 \\
$250 \mathrm{ml}$ sliced champignon & 0.048777 \\
$900 \mathrm{ml}$ sliced champignon & 0.175294 \\
Canned Champignon & 0.409802 \\
\hline
\end{tabular}

\section{Objective Function}

The purpose of this production plan modeling is to maximize the profits obtained by PT X. The expected goals in this planning model are minimizing excess raw materials, minimizing production costs, maximizing revenue, meeting demand, and maximizing the use of available man hours. Therefore we need priority factors of each target to determine their level of importance. Priority factors were determined from the survey results of several participants. The experts that participated in this study were production assistant managers, purchasing assistant managers, logistics assistant managers, QA assistant managers, vegetable product supervisors, and QC supervisors in PT X. Priority level was calculated by using pairwise comparison. The final priority level results based on the survey can be seen in Table 10.

Table 10. Objective constraint priority level

\begin{tabular}{lc}
\hline \multicolumn{1}{c}{ Objective Constraint } & Priority level \\
\hline Seales income & 0.18815 \\
Production cost & 0.13268 \\
Raw material needed & 0.30913 \\
Man hour needed & 0.09116 \\
Demand fulfillment & 0.27887 \\
\hline
\end{tabular}

The following is the objective function that based on all of the objective constraints and their priority levels.

Min $\mathrm{Z}=\left(0.309133 \mathrm{x}\left(\mathrm{d}_{1}+\mathrm{d}_{2}\right)\right)+\left(0.27887 \mathrm{x}\left(\mathrm{d}_{3}+\mathrm{d}_{4}\right.\right.$ $\left.\left.+\mathrm{d}_{5}+\mathrm{d}_{6}+\mathrm{d}_{7}+\mathrm{d}_{8}+\mathrm{d}_{9}+\mathrm{d}_{10}+\mathrm{d}_{11}+\mathrm{d}_{12}+\mathrm{d}_{13}+\mathrm{d}_{14}\right)\right)$ $+\left(0.18815 \times \mathrm{d}_{15}\right)+\left(0.132683 \times\left(\mathrm{d}_{16}\right)+\right.$ $\left(0.091164 \mathrm{x}\left(\mathrm{d}_{17}+\mathrm{d}_{18}\right)\right)$.

\section{Planning Result}

Calculation of product combination plans using goal programming models was performed by LINGO 18.0 application. It is a comprehensive software that can assist in optimizing, analyzing, and solving programming problems. The planning result shows that the plan meets the objective constraints of maximizing the use of available raw material, meeting the production revenue target, and minimizing the production cost. The plan also meets the demand for all products except fresh champignon which was less than the total demand and $900 \mathrm{ml}$ sliced champignon which was more than the total demand. The total production based on the plan that has been made for January 2020 can be seen in Table 11.

The plan showed the total production of fresh champignon products did not reach the number of demand. This was due to the limitations of existing resources since fulfilling product demand is the second priority of company objective. This study result did not fulfill some objective constraints but provided the most satisfying solution that might be obtained based on the priority level and existing constraints.

\section{Sensitivity Analysis}

Sensitivity analysis is to check possible parameter changes. This analysis is needed to see certain changes that can be tolerated before the optimal solution begins to lose its optimality. The sensitivity analysis result from the planning can be seen in Table 12.

Table 11. Planning result

\begin{tabular}{lcc}
\hline \multicolumn{1}{c}{ Objective Constraint } & Target & Planning Result \\
\hline Raw Material Needed (kg) & $39,986.5$ & 39,986 \\
Fresh champignon fulfillment & 30,280 & 22,584 \\
250 mL Whole Champignon fulfillment & 4,499 & 4,499 \\
900 mL Whole Champignon fulfillment & 2,571 & 2,571 \\
250 mL Sliced Champignon fulfillment & 4,567 & 4,567 \\
900 mL Sliced Champignon fulfillment & 7,688 & 32,306 \\
Canned Champignon fulfillment & 85 & 85 \\
Production Revenue (IDR) & $1,400,000,000$ & $1,400,008,000$ \\
Production Cost Needed (IDR) & $1,000,000,000$ & $970,982,000$ \\
Man hour Needed & 6,476 & 7,225 \\
\hline
\end{tabular}


Table 12. Sensitivity analysis result

\begin{tabular}{lcc}
\hline \multicolumn{1}{c}{ Objective Constraint } & Allowable increase & Allowable decrease \\
\hline Raw Material & $5,245.3$ & $15,391.6$ \\
Fresh champignon & infinity & 7,696 \\
$250 \mathrm{ml}$ Whole Champignon & 49,265 & 4,499 \\
$900 \mathrm{ml}$ Whole Champignon & 24,869 & 2,571 \\
$250 \mathrm{ml}$ Sliced Champignon & 46,295 & 4,567 \\
$900 \mathrm{ml}$ Sliced Champignon & 24,617 & infinity \\
Canned Champignon & 17,244 & 85 \\
Production Revenue & $50,049,260$ & $81,616,220$ \\
Production Cost & infinity & $29,024,050$ \\
Man hour & 749 & infinity \\
\hline
\end{tabular}

The sensitivity analysis can determine the impact of uncertainty on optimal solution quality (Taha, 2007). It can help to balance the uncertainty aspects of the model in the future (Kosmidou and Zopounidis 2004) and is very important because in the reality the condition is always changing. By changing the process condition, the model's parameters that have been formulated will be affected, so that the optimal conditions of the initial model will be changed as well. Based on the sensitivity analysis, the total production of each product based on the product combination plans are in the range of allowable increase and decrease.

\section{Model Verification}

Verification is carried out to find whether the model can represent the predicted data. An important step after forecasting is to verify the forecast. Verification is used to select the forecasting model that most accurately represents reality (Antonanzas et al., 2020). This forecast verification was to verify the forecasted data used in this product combination planning model. The basic principle of verification is to sort data, one set of data is used to get a model and another set of data is used for the purposes of estimating the risk of using the model. Verification was done by using a Moving Range chart to compare observed values (actual data) with forecasted values of the same needs. Moving Range is a type of control chart used in statistical quality control (Hasan et al., 2019). In this case, this Moving Range was used to check the quality of the forecast used. Based on the moving chart, there was no data that is outside of the control limits so that the forecasting method can be stated as representative.

\section{CONCLUSION AND RECOMMENDATION}

\section{Conclusion}

Based on the product combination planning in this study, the total production of fresh champignon was $22,584 \mathrm{~kg}, 250 \mathrm{~mL}$ whole champignon was 4,499 items, $900 \mathrm{ml}$ whole champignon is 2,571 items, 250 $\mathrm{ml}$ sliced champignon was 4,567 items, $900 \mathrm{~mL}$ of sliced champignon was 32,306 items, and canned champignon was 85 items. The results of this planning meet the objective constraints of maximizing the use of available raw material, meeting the production revenue target, and minimizing the production cost. However, the plan did not meet the objective constraints of maximizing the use of available man hour and meeting the products demand.

Similarly, the plan did not fulfill some objective constraints set by the company because of the limitations of raw material, product demand, man hour, production cost, and revenue targets, while there were five objective constraints that have an opposite relationship to be achieved. In conclusion, the plan was the most satisfying possible solution. The production plan from this study is more measurable and clear compare to the plan being implemented by the company.

\section{Recommendation}

Further planning on a daily basis with detailed product combination is needed in order to be more easier for implementation. In addition, improvements are needed in models that are closer to real conditions in the company related to differences in champignon quality and differences in the price of fresh champignon products.

\section{REFERENCES}

Akram K, Ahn JJ, Yoon SR, Kim GR, Kwon JH. 2012. Quality attributes of Pleurotus eryngii following gamma irradiation. Postharvest Biology and Technology. 66: 42-47. doi: 10.1016/j.postharvbio.2011.12.001.

Amalia R, Yulianto T, Sari IN, Faisol. 2016. Penerapan metode goal programming untuk optimasi biaya produksi pada produk air mineral Aqua di Bangkalan. Zeta-Math Journal. 2 (2): 31-36.

Antonanzas J, Perpinan-Lamigueiro O, Urraca R, Antonanzas-Torres F. 2020. Influence of electricity market structures on deterministic solar forecasting verification. Solar Energy. https://doi.org/10.1016/j.solener.2020.04.017

Box GP and Jenkins GM. 1991. Time Series Analysis: Forecasting and Control. California (USA): Prentice-Hill. 
Hasan MN, Begum AA, Rahman M, Mollah NH. 2019. Robust identification of significant interactions between toxicogenomic biomarkers and their regulatory chemical compounds using logistic moving range chart. Computation Biology and Chemistry. 78: 375381.

Hillier FS and Lieberman GJ. 2001. Introduction to Operations Research Seventh Edition. New York (USA): MCGraw-Hill

Ho H. 2019. The supplier selection problem of a manufacturing company using the weighted multi-choice goal programming and MINMAX multi-choice goal programming. Applied Mathematical Modelling. 75: 819836. https://doi.org/10.1016/j.apm.2019.06.001.

Hocinea A, Zheng-Yun Zhuang Z, Kouaissaha N, Li D. 2020. Weighted-additive fuzzy multichoice goal programming (WA-FMCGP) for supporting renewable energy site selection decisions. European Journal Operational Research. 285: 642-654. https://doi.org/10.1016/j.ejor.2020.02.009.

Komsiyah S, Meiliana, dan Centika HE. 2018. A fuzzy goal programming model for production planning in furniture company. Procedia Computer Science. 135: 544-552. doi: 10.1016/j.procs.2018.08.207.

Kosmidou K dan Zopounidis C. 2004. Goal Programming Techniques for Bank Asset Liability Management. New York (USA): Kluwer Academic Publishers.

Kouaissah N dan Hocine A. 2020. Optimizing sustainable and renewable energy portfolios using a fuzzy interval goal programming approach. Computers \& Industrial Engineering. 114: 1-12. https://doi.org/10.1016/j.cie.2020.106448.

Liu F, Zhang J, Zhang W, Pedrycz W. 2020. Decision making with a sequential modeling of pairwise comparison process. Knowledge-Based System. 195: 1-12.

https://doi.org/10.1016/j.knosys.2020.105642

Montgomery DC, Jennings CL, dan Kulahci M. 2008. Introduction to Time Series Analysis and Forecasting. New Jersey (US): John Wiley \& Sons, Inc.

Muszyńska B, Piotrowska J, Krakowska A, Gruba A, Kała K, Sułkowska-Ziaja K, Kryczyk A, Opoka W. 2017. Study of physiologically active components in different parts of fruiting bodies of varieties of Agaricus bisporus (white mushroom). Journal European Food Research and Technology. 243: 2135-2145. doi: 10.1007/s00217-017-2914-2.

Ramos M, Burgos N, Barnard A, Evans G, Preece J, Graz M, Ruthes AC, JiménezQuero A, Martínez-Abad A, Vilaplana F. 2019. Agaricus bisporus and its by-products as a source of valuable extracts and bioactive compounds. Food Chemistry. 292: 176-187. https://doi.org/10.1016/j.foodchem.2019.04.0 35.

Taha HA. 2007. Operations Research: An Introduction. New Jersey (USA): Pearson Prentice Hall.

Tiwari S dan Kumar A. 2018. Comparison between goal programming and other linear programming methods. International Journal Research in Applied Science \& Engineering Technology. 6 (5): 926-929. http://doi.org/10.22214/ijraset.2018.514

Vincent O, Ijedinma NO, and Onyemachi UC. 2018. Production planning and organizational effectiveness. Strategic Journal Business and Social Science. 1: 1-28.

https://www.researchgate.net/publication/330 715992 